
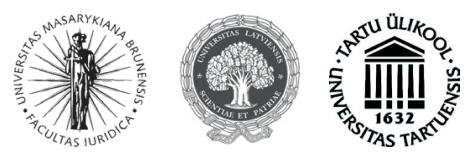

ISSN 1392-6195 (print) ISSN 2029-2058 (online) JURISPRUDENCIJA JURISPRUDENCE 2013, 20(3), p. 1081-1094.

\title{
SUSIJUNGIMAS KAIP NUOSAVYBĖS TEISĖS IGIJIMO IR PRARADIMO PAGRINDAS LIETUVOS CIVILINĖJE TEISĖJE
}

\author{
Ramūnas Birštonas \\ Mykolo Romerio universiteto Teisès fakulteto \\ Civilinès justicijos institutas \\ Ateities g. 20, LT-08303 Vilnius, Lietuva \\ Telefonas (+370 5) 2714587 \\ Elektroninis paštas birstonas@mruni.eu
}

Pateikta 2013 m. rugpjūčio 14 d., parengta spausdinti 2013 m. rugsèjo 20 d.

doi:10.13165/JUR-13-20-3-11

Anotacija. Straipsnyje analizuojamas klausimas, ar susijungimas gali büti laikomas vienu iš siuo metu taikomu Lietuvos civilineje teiseje nuosavybès teisés igijimo ir praradimo pagrindu. Šis pagrindas buvo skiriamas jau romenu teiseje ir yra taikomas kitose Europos valstybese, tačiau jis nèra minimas nei Lietuvos Respublikos civiliniame kodekse ar kituose civiliniuose istatymuose, nei teismu sprendimuose, nei Lietuvos teisès doktrinoje. Apsiribojant lingvistiniu aiškinimo metodu galima bütuc daryti išvada, kad Lietuvoje susijungimas kaip nuosavybès teisès igijimo bei praradimo pagrindas nèra taikomas. Tačiau nuodugnesnè civiliniu istatymu analize leidžia daryti priešinga išvadą. Straipsnyje analizuojama susijungimo samprata ir taikymo tikslai, taip pat kitu Europos valstybiu patirtis bei Bendrosios pagrindu. sistemos projektas (DCFR). Taip pat atliekama Lietuvos civiliniu istatymu ir teismu praktikos analize, kuri atskleidžia, jog susijungimas yra ir reglamentuojamas pozityviojoje teisejje, ir taikomas praktikoje, be to, reguliavimas yra kai kuriais atžvilgiais perteklinis ir nesuderintas.

Reikšminiai žodžiai: daiktinè teisè, daiktas, nuosavybès teise, susijungimas, civilinis kodeksas. 


\section{Ivadas}

Straipsnio tikslas yra atsakyti ị konkretų klausimą: ar šiuo metu veikiančioje Lietuvos civilinès teisès sistemoje galima išskirti susijungimą (lot. accessio) kaip savarankišką nuosavybės teisés igijimo ir praradimo pagrindą, o jei taip - kokios yra jo reglamentavimo ypatybès. Toks klausimas kyla, visų pirma, todèl, kad susijungimas nèra expressis verbis minimas kaip savarankiškas nuosavybès teisès įgijimo pagrindas nei Lietuvos Respublikos civiliniame kodekse ${ }^{1}$ (toliau - CK), nei kituose Lietuvos Respublikos civiliniuose ịstatymuose (kai kurios kilnojamujų daiktų susijungimo pasekmès yra reglamentuojamos CK 4.54 straipsnyje, tačiau šios pasekmès yra ne nuosavybès teisès ịgijimas ar praradimas, tačiau asmeninès nuosavybės teisès transformacija ị bendrosios nuosavybès teisę). Dar daugiau, tokio nuosavybès teisès ịgijimo pagrindo neịvardija ir dabartinè rašytinè Lietuvos civilinès teisès doktrina ${ }^{2}$. Galiausiai, Lietuvos teismai nurodyto nuosavybės teisès pagrindo taip pat nėra ịvardiję, kas natūralu, turint galvoje, kad nuosavybès teisè gali būti ịgyjama tik ịstatymo nustatytais pagrindais (CK 4.47 straipsnis) ir teismai savo nuožiūra naujo pagrindo sukurti negali. Kita vertus, susijungimas buvo skiriamas romėnų teisèje ir yra pripažįstamas daugelio šiuolaikinių valstybių, ypatingai tų, kurios priklauso civilinès teisès tradicijai. Taigi, kyla klausimas, ar Lietuvos daiktinè teisè istorinių transformacijų procese ,pametė“ ši gerai žinomą nuosavybès teisès įgijimo pagrindą ir sėkmingai išsiverčia be jo? Ar, atvirkščiai, susijungimas, nors ir neįvardytas, egzistuoja ir atlieka teisiškai reikšmingą funkciją?

Straipsnyje analizuojamas klausimas yra aktualus bent dèl dviejų priežasčių. Pirma, minèta, susijungimas yra vienas iš civilinès teisès tradicijos, kuriai priklauso ir Lietuva, svarbių instrumentų, atliekantis nuosavybès teisès paskirstymo tarp asmenų funkciją ir sistemiškai susijęs su kitais nuosavybès teisès ịgijimo ir praradimo pagrindais. Jei Lietuvos civilinèje teisèje šio nuosavybès teisès ịgijimo bei praradimo pagrindo išties nèra, tuomet kyla klausimas, kokiais teisiniais instrumentais jis yra pakeičiamas, ar galbūt Lietuvos teisinei praktikai apskirtai nebūdingi ginčai, kuriems minimas pagrindas būtų reikšmingas. Tačiau, užbėgant už akių, galima pastebėti, kad susijungimui reikšmingų normu galima rasti tiek nacionaliniame teisiniame reguliavime, tiek Lietuvos teisine praktika pakankamai dažnai susiduria su poreikiu taikyti analizuojamą pagrindą. Nurodytos aplinkybès reiškia, kad doktrina turi imtis darbo ir išryškinti susijungimo vietą Lietuvos daiktinès teisès sistemoje ir šio pagrindo taikymo galimybes.

Antra, susijungimo analize yra reikalinga atsižvelgiant ị vykstančias Europos teisės vienodinimo iniciatyvas. Ilgą laiką buvusi teisès derinimo nuošalyje, daiktinè teisè vis dažniau ir daugiau pakliūna tiek ị akademinès Europos bendruomenès, tiek ị teisèkūros iniciatyvų akiratị. Kartu kyla poreikis nustatyti atitikimus ir neatitikimus tarp Europos valstybių (kurios, sakyta, dažniausiai aiškiai išskiria susijungimą kaip savarankišką nuosavybès teisès ịgijimo ir praradimo pagrindą) ir Lietuvos teisinių sistemų.

1 Lietuvos Respublikos civilinis kodeksas. Valstybès žinios. 2000, Nr. 74-2262.

2 K. Laurinavičius greta minèto CK 4.54 straipsnio papildomai mini pastatų, pastatytų ant kitam asmeniui priklausančio žemės sklypo, teisinio likimo klausimą užstatymo teisès (CK 4.164 straipsnis) kontekste, tačiau plačiau susijungimo instituto neanalizuoja. Žr. Baranauskas, E., et al. Daiktiné teisé. Vadovèlis. Vilnius: Mykolo Romerio universiteto Leidybos centras, 2010, p. 116-117. 
Atsakant ị iškeltą klausimą keliami tokie uždaviniai. Pirma, išanalizuoti susijungimo, kaip nuosavybės teisès ịgijimo ir praradimo pagrindo, sampratą ir šio pagrindo tikslą. Antra, apžvelgti susijungimo institutą civilinę Europos teisès tradiciją reprezentuojančių Europos valstybių (Prancūzijos, Vokietijos) teisèje, taip pat šio instituto reglamentavimą šiuo metu svarbiausiame europiniame soft law instrumente - Bendrosios pagrindų sistemos projekte (toliau - ir BPSP). Šio uždavinio ịgyvendinimas leistų suteikti tiek visapusiškesni analizuojamo instituto suvokimą, tiek jo vienodinimo perspektyvas. Trečia, atlikti Lietuvos Respublikos teisès aktų ir jų taikymo teismų praktikoje analizę ir, apibendrinus, nustatyti, ar susijungimas gali būti skiriamas kaip savarankiškas pagrindas.

Straipsnyje taikomas dokumentų analizès metodas. Analizuojami Lietuvos Respublikos, tiriamų užsienio valstybių teisès aktai ir teismų sprendimai, Bendrosios pagrindų sistemos projektas, taip pat mokslinè literatūra.

Kaip jau minèta, susijungimo instituto taikymo klausimai Lietuvoje mokslinejje literatūroje visiškai nenagrinèti. Užsienio literatūroje galima rasti tik nacionalinių užsienio valstybių teisès analizę. Atskirai paminėtina lyginamoji L. van Vlieto studija, skirta kilnojamųų daiktų prisijungimui prie nekilnojamujų ${ }^{3}$, taip pat susijungimui yra skirta nemažai dėmesio (to paties autoriaus) Ius Commune praktikumų projekto pagrindu išleistame lyginamajame tyrime, skirtame Europos daiktinei teisei ${ }^{4}$. Tačiau nè vienoje nurodytoje publikacijoje Lietuvos teisè nebuvo nagrinèjama.

\section{Susijungimo, kaip nuosavybès teisès igijimo ir praradimo pagrindo, samprata ir tikslai}

Susijungimas, kaip nuosavybès teisès igijimo ir praradimo pagrindas, yra platesnio daiktinès teisès principo - vieningumo - taikymo konkreti išraiška. Šị principą išreiškia glausta vokiečių pandenktistų formulè: vienas daiktas - viena nuosavybès teisé5 ${ }^{5}$ Tai reiškia, kad daiktinių teisių objektas yra vieningas ir vieninga yra to objekto atžvilgiu egzistuojanti nuosavybės teisè, todẻl negali egzistuoti skirtingų asmenų skirtingos nuosavybès teisès $i$ atskiras to paties daikto dalis ${ }^{6}$.

Šis principas grindžiamas tuo, jog pagrindinis daiktinių teisių skiriamasis požymis - absoliutus, erga omnes pobūdis gali būti pateisinamas ir igyvendinamas tik tuomet, jei visiems civilinių santykių dalyviams yra aišku, kas yra šių teisių objektas. Kitaip

3 Van Vliet, L. P. W. Accession of Movables to Land: I. Edinburg Law Review. 2002, 6; Van Vliet, L. P. W. Accession of Movables to Land: II. Edinburg Law Review. 2002, 6.

4 Cases, Materials and Text on Property Law. Ed. Van Erp S., Akkermans B. Oxford and Portland, Oregon: Hart Publishing, 2012.

5 Plačiau žr. Storme, E. M. Property Law in Comparative Perspective. Part I. General Notions [interaktyvus]. KU Leuven Centre for Advanced Legal Studies, 2004 [žiūrèta 2013-07-28]. <http://www.storme.be/ comprop1.pdf $>$, p. 22-23.

6 Bendrosios nuosavybės teisès institutas nepaneigia, bet, atvirkščiai, patvirtina išdèstytą principą: idealiosios dalies samprata labai aiškiai rodo nuostatą laikyti daiktą vieningu ir neleisti atsirasti nuosavybès teisei i neatskirtas fizines daikto dalis. 
sakant, daiktinių teisių absoliutumas kaip savo sąlygą suponuoja trečiųų asmenų informavimą. Netaikant vieningumo principo būtų gerokai sunkiau nuspręsti, kuris turtas savininkui priklauso nuosavybės teise, ar ị to paties daikto dalis nèra trečiųų asmenų interesų. Tokiu būdu vieningumas papildo kitą informacinio pobūdžio daiktinių teisių principą - viešumą.

Susijungimas yra tas teisinis instrumentas, kuris pašalina teisinių santykių neapibrèžtumą, sukeldamas nuosavybės teisès praradimą vieno susijungusio daikto, laikomo šalutiniu, savininkui ir vieningos nuosavybès teisès pripažinimą daikto, laikomo pagrindiniu, savininkui. Kaip jau minèta, tokios daiktinès teisinès susijungimo pasekmès skirtos apsaugoti civilinių santykių dalyvius, kurie, sudarydami sandorius dẻl daikto, gali būti tikri, kad ateityje nepaaiškès konkuruojančių teisių ị to paties daikto dalis. Be to, susijungimo taisyklè yra pagrindžiama ir vertes išsaugojimo doktrina - paprastai visas daiktas yra vertas daugiau nei jo dalys, imant jas atskirai, todèl teisè, pašalindama kitų asmenų teises ị daikto dalis, apsaugo nuo daikto dalijimo ir, atitinkamai, vertès praradimo?.

Susijungimas tradiciškai priskirtinas prie pirminių nuosavybės teisès igijimo pagrindų, nes nuosavybès teisès ịgijimas nereikalauja nei šalutinio, nei pagrindinio daikto savininko valios. Pagrindinio ir šalutinio daiktų susijungimas yra juridinis faktas - įvykis arba juridinis poelgis, tačiau ne sandoris ${ }^{8}$.

Viena Lietuvoje išspręstų civilinių bylų, atrodo, buvo specialiai skirta iliustruoti anksčiau aptartus aspektus praktikoje. Minimoje byloje ${ }^{9}$ ieškovui iš varžytynių buvo parduotas pastatas; prieš įsigyjant pastatas buvo tvarkingas, su stogu, langais ir durimis. Tačiau, praèjus kuriam laikui, reikalavimus ị ankstesniji pastato savininką turèjęs rangovas išarde ir išsigabeno stogo dangą, langus ir duris. Šioje, kaip sakyta, chrestomatinès bylos titulo nusipelniusioje byloje yra labai aiškus dviejų teisètų interesų konfliktas statybos darbus atlikęs rangovas turi teisę gauti atlyginimą už atliktus darbus ir pateiktas medžiagas, tuo tarpu varžytynėse daiktą ịgijęs asmuo turi teisètą interesą turèti nuosavybès teise tokị daiktą, kokios būklès šis buvo ịgijimo metu, nes būtent daikto būklè tuo momentu leido priimti ịgijejjui sprendimą dèl jo vertès ir siūlyti atitinkamą kainą. Jei aposteriori dalis daikto, šiuo atveju stogo danga, langai ir durys, yra atskiriami ir paimami kitų asmenų, daikto verte neabejotinai mažèja, o kartu kyla neabejotini nuostoliai savininkui. Taigi, pateiktoje situacijose pagrindinis klausimas - kuriam iš (preziumuotina, sąžiningų) asmenų teks nuostolių rizika: rangovui ar naujajam daikto savininkui. Susijungimo taisykle ị ş̣ klausimą atsako aiškiai - rizika tenka rangovui (beje, rangovas šią riziką gali valdyti imdamasis papildomų savo interesų apsaugos priemonių). Prie nekilnojamojo daikto prisijungusios medžiagos (stogo danga, durys, langai) jau tapo pastato dalimis ir jas apėmè vieninga pastato nuosavybės teisé; tuo tarpu rangovo ar kitų

$7 \quad$ Supra note 4, p. 618-620.

8 Tačiau skirtingose valstybėse suteikiama skirtinga reikšmė abiejų daiktų savininkų valiai, sprendžiant, ar daiktas susijungè, ar ne. Plačiau žr. Van Vliet, L. P. W. Accession of Movables to Land: II. Edinburg Law Review, supra note 3, p. 212-216.

9 Lietuvos Aukščiausiojo Teismo Civilinių bylų skyriaus teisëjų kolegijos 2008 m. spalio 21 d. nutartis civilinèje bylioje Nr. 3K-3-491/2008. 
asmenų nuosavybės (ar kitos daiktinės) teisès pasibaigè. Aptariamoje situacijoje išryškèja ir kitas civilinės teisès doktrinai žinomas principas - daiktinių teisių pirmumo (arba stiprumo) lyginant su prievolinėmis teisėmis principas. Aptariamu atveju varžytynėse daiktą igijęs asmuo - daikto savininkas, turi stipresnę teisę prieš rangovą, kuris turi tik prievolines teises, be to, rangovo prievolinès teisès yra nukreiptos ne ị savininką, vadinasi, ir ne ị jo turtą, o ị ankstesnị savininką. Tokiu būdu susijungimo taisyklè apsaugotų tiek turto igijejjo interesus, tiek užtikrintų, kad viso pastato vertė nebus prarasta, išardant jị dalimis ${ }^{10}$.

\section{Susijungimo instituto lyginamoji analizè}

Kaip jau minėta, susijungimo keliamas teisines pasekmes reglamentavo jau romėnų teisè: jos randamos tokiuose ankstyvuosiuose civilinės teisès tradicijos šaltiniuose kaip Dvylikos lentelių ịstatymai. Jie numate draudimą išimti pastato ar vynuogyno jungiamąją siją, nepaisant to, kad ši nuosavybės teise priklausẻ kitam asmeniui ${ }^{11}$. Vèlesnèje romènų teisès raidoje susijungimas (lot. accessio) išsiskyrè kaip savarankiškas nuosavybès teisès igijimo pagrindas; buvo skiriami keli siauresni accesssio atvejai: nekilnojamuju daiktų susijungimas, kilnojamųjų daiktų susijungimas su nekilnojamuoju, kilnojamųų daiktų susijungimas ${ }^{12}$.

Prancūzijos Code civil (toliau $-\mathrm{CC})^{13}$ daikto vieningumo klausimus reguliuoja droit d'accession institutas, kuriam skirta solidi vieta ir apimtis - jis užima didžiają II knygos 2 skirsnio, skirto nuosavybès teisei, dali ${ }^{14}$. Bendroji CC 546 straipsnio norma nustato, jog nuosavybès teisè ị daiktą, kilnojamajị ar nekilnojamajji, suteikia teisę ị visus šalutinius prisijungusius daiktus, nesvarbu, ar dẻl natūralių, ar dirbtinių priežasčių. Toliau dviejuose skyriuose (CC 547-577 straipsniai) detaliai nagrinėjamos ịvairios droit d'accession taikymo situacijos, iš kurių matyti, kad šis institutas apima daugeli nuosavybès teisès igijimo, praradimo bei modifikavimo pagrindų, kuriuos Lietuvos CK skiria kaip savarankiškus, pavyzdžiui, daikto duodamų vaisių pasisavinimą, daikto perdirbimą. Kalbant apie susijungimą siauraja prasme, Prancūzijos reglamentavimas išskiria kilnojamųjų ir nekilnojamųjų daiktų atvejus. Kilnojamųjų daiktų susijungimui svarbiausia taisyklè yra įtvirtinta CC 567 straipsnyje, nustatant, kad dẻl tokio susijungimo pasekmių (konkrečiai - kuris daiktas pagrindinis, o kuris - šalutinis), sprendžiama pagal prigimti-

10 Pratęsiant situaciją iki kraštutinumo, tas pats ar kiti rangovai galètų toliau ardyti pastatą, pasiimdami „Savo“ sienas, perdangas ir pamatus. Kas tokiu atveju liktų nuosavybés teisės ị pastatą objektu?

11 Vèlyvis, S.; Jonaitis, M. XII lenteliu istatymai ir ju komentaras. Vilnius: Teisinès informacijos centras, 2007, p. 66, 70.

12 Nekrošius, I.; Nekrošius, V.; Vèlyvis, S. Romènu teisè. Vilnius: Justitia, 1999, p. 134; van Zyl, D. H. History and Principles of Roman Law. Durban: Butterworths, 1983, p. 156-165.

13 Prancūzijos Respublikos civilinis kodeksas (Code civil) [interaktyvus]. [žiūrèta 2013-07-28]. <http:// www.legifrance.gouv.fr/affichCode.do?cidTexte=LEGITEXT0000060 70721>.

14 Faktiškai susijungimo klausimus reglamentuoja ir kai kurios antrosios knygos pirmojo skirsnio normos, pvz., CC 523 str., nustatantis, kad vamzdžiai, kuriais vanduo patenka ị nekilnojamaji daiktą, laikomi nekilnojamaisiais daiktais ir nekilnojamojo daikto, su kuriuo yra susijungę, dalimi. 
nị teisingumą ${ }^{15}$. Tuo tarpu susijungimo su nekilnojamuoju daiktu situacijoms pagrindinè taisyklė yra ta, kad pagrindinis daiktas visada yra žemès sklypas, o visi ant žemès sklypo paviršiaus esantys augalai, statiniai ar kitokie objektai yra šalutiniai daiktai ir pagal bendrają taisyklę laikytini žemės sklypo savininko nuosavybe (CC 553-555 straipsniai), nebent būtų įrodyta kitaip. Svarbu pridurti, kad Prancūzijos kasacinio teismo praktikoje pripažįstama, jog susijungimą reglamentuojančios teisès normos yra dispozityvios, todèl teisinių santykių subjektai gali susitarti dèl kitokių susijungimo pasekmių ${ }^{16}$.

Vokietijos civiliniame kodekse (Bürgerliches Gesetzbuch) ${ }^{17}$ (toliau - BGB) taip pat yra įtvirtintos specialios nuostatos, reglamentuojančios daiktų susijungimą. BGB 946 straipsnis yra skirtas kilnojamojo daikto susijungimo su nekilnojamuoju daiktu atvejui ir nustato, kad kilnojamajam daiktui susijungus su žemés sklypu tokiu būdu, kad jis tampa esmine žemès sklypo dalimi, nuosavybès teisè ị žemės sklypą apima ir tokị daiktą. BGB 947 straipsnio, skirto kilnojamųų daiktų susijungimui, pirmoji dalis nustato, kad kilnojamiesiems daiktams susijungus tokiu būdu, kad jie tampa vieningo daikto esminėmis dalimis, ankstesnieji savininkai tampa šio daikto bendraturčiais; antroji to paties straipsnio dalis nustato specialią taisyklę, kai vienas iš daiktų laikytinas pagrindiniu daiktu, būtent jo savininkas tampa vieninteliu nuosavybės teisės turètoju. Abiem - ir prisijungimo prie nekilnojamųjų, ir kilnojamųjų daiktų susijungimo atvejais nurodoma ta pati sąlyga - tapimas daikto esminèmis dalimis. Pastaroji sąvoka yra plètojama BGB 93 straipsnyje, pagal kurị esminėmis dalimis laikytinos daikto dalys, kurios negali būti atskirtos nuo daikto kurio nors iš jų nesunaikinant arba nepakeičiant jo pobūdžio; taip pat specialiai pabrèžiama, kad esminès daikto dalys negali būti atskirų teisių objektu. BGB 94-95 straipsniai toliau išplètoja esminių dalių sąvoką nekilnojamụjų daiktų atžvilgiu.

Neabejotinai šiuo metu svarbiausiame Europos daiktinès teisès akademiniame dokumente - Bendrosios pagrindų sistemos projekte susijungimas yra reglamentuojamas VIII knygos, skirtos nuosavybės teisès ị kilnojamuosius daiktus igijimui ir praradimui ${ }^{18}$ 5 skyriuje, konkrečiai šios knygos 5:101, 5:203 straipsniuose. Pastarojo straipsnio 1 ir 2 dalyse nustatoma pagrindinè taisyklè, kad esant situacijai, kai kilnojamieji daiktai, nuosavybès teise priklausantys skirtingiems asmenims, susijungè taip, kad jų atskyrimas būtų neịmanomas arba ekonomiškai nenaudingas, ir kai viena iš sudėtinių dalių laikytina pagrindine dalimi, šios dalies savininkas igyja nuosavybès teisę ị visą daiktą, o šalutinių dalių savininkas ar savininkai igyja teisę reikalauti kompensacijos. BPSP susijungimas yra susietas ir su kitomis svarbiomis sąlygomis, iš kurių paminėtina, kad pirmiausia susijungimo pasekmès gali būti sureguliuotos šalių susitarimu ir tokiu būdu 5:203 straipsnio taisyklès galètų būti modifikuotos (5:101 straipsnio 1 dalis); jei daiktus galima atskirti nepadarant rimtos ekonominès žalos, tuomet susijungimas nepripažįsta-

15 Malaurie, Ph.; Aynes, L. Cours de droit civil. Les Biens. Paris: Cujas, 1994, p. 118.

16 Supra note 4, p. 652.

17 Vokietijos Federacinès Respublikos civilinis kodeksas (Bürgerliches Gesetzbuch) [interaktyvus]. [žiūrèta 2013-07-28]. <http://www.gesetze-im-internet.de/bgb/index.html>.

18 Principles of European Law. Acquisition and Loss of Ownership of Goods. Sellier European Law Publishers. 2011. 
mas, o kiekvienas savininkas išlaiko teisę reikalauti grąžinti jam nuosavybės teise priklausantị daiktą; jei nẻ viena iš sudedamujų daikto dalių negali būti laikoma pagrindine, tuomet dalių savininkai tampa viso daikto bendraturčiais proporcingomis savo dalių vertei dalimis (5:203 straipsnio 3 dalis); galiausiai, bendraturčių santykiai kyla ir tuo atveju, jei pagrindinès dalies savininkas atlieka sujungimą, žinodamas, kad antraeilè dalis nuosavybès teise priklauso kitam asmeniui ir kad šis nesutinka su sujungimu, nebent pagrindinės dalies vertė yra daug didesnè nei šalutinès dalies (5:203 straipsnio 4 dalis). Kalbant apie BPSP verta priminti, kad jo taikymo sritis apima tik kilnojamuosius daiktus, todèl natūralu, kad nuosavybès teisès klausimai susijungimo su nekilnojamaisiais daiktais atvejais liko už šio akademinio projekto ribų.

\section{Susijungimo reglamentavimas Lietuvoje}

Kaip minėta, Lietuvos pozityviojoje daiktineje teisėje susijungimas nėra expressis verbis išskirtas kaip savarankiškas nuosavybės teisès igijimo bei praradimo pagrindas. Susijungimas, tiesa, reglamentuojamas CK 4.54 straipsnyje, kurio taikymo sritis yra apribota kilnojamųjų daiktų atžvilgiu; šio straipsnio pirmoji dalis numato, kad nebegalint sujungtų kilnojamųjų daiktų atskirti ir nesant savininkų susitarimo dẻl daiktų sujungimo, atsiradęs naujas kilnojamasis daiktas laikomas bendraja daline nuosavybe, o antroji dalis skirta atvejui, kai susijungusius daiktus galima atskirti (tokiu atveju nuosavybès teisès pokyčių nèra). Kyla klausimas, ar visi susijungimo atvejai turètų būti sprendžiami taikant šią teisès normą. Tačiau ịdèmesnė CK analizė rodo, kad susijungimo taisyklè, lemianti visai kitas teisines pasekmes, faktiškai yra įtvirtinta ir daugelyje kitų civilinès teisès normų.

Pirma, CK 1.98 straipsnio 2 dalis ịtvirtina tai, ką būtų galima pavadinti „,nepilna susijungimo taisykle“. Nurodyta norma yra suformuluota ne kaip nuosavybės teisés ịgijimo ir praradimo pagrindas, o kaip norma-definicija, kuri gali atlikti ir nuosavybès teisès paskirstymo reikšmę ${ }^{19}$. Konkrečiai CK 1.98 straipsnio 2 dalyje pateiktame nekilnojamojo daikto apibréžime nurodyta, kad greta žemės (tiksliau - žemės sklypo) ${ }^{20}$ tokiais laikomi ir kiti daiktai, kurie susiję su žeme ir kurių negalima perkelti iš vienos vietos i kitą nepakeitus jų paskirties bei iš esmès nesumažinus jų vertès, ir yra pateikiamas pavyzdinis tokių daiktų sąrašas - pastatai, ̨̣renginiai, sodiniai ir kiti daiktai, kurie pagal paskirtị ir prigimtị yra nekilnojamieji. Nurodyta norma išreiškia tradicinę civilinès teisės nuostatą, kad žemès sklypo, kaip pagrindinio nekilnojamojo daikto, prigimtis paverčia nekilnojamaisiais ir prie jos prijungtus daiktus. Pastatai ir kai kurie įrenginiai gali būti

19 Tai, kad normos-definicijos kartu gali atlikti savarankišką reguliacinę funkciją, patvirtina ir teismų praktika. Pavyzdžiui, aiškindami miško žemès savininko teisių apimtį teismai rẻmėsi Lietuvos Respublikos miško ịstatymo 2 straipsnyje patektu miško žemès apibrěžimu, iš kurio išvedè draudimą miško žemèje statyti kitus statinius, neinurodyta šiame apibrèžime. Lietuvos Aukščiausiojo Teismo Civiliniųbylų skyriaus teisèjų kolegijos $2012 \mathrm{~m}$. vasario $8 \mathrm{~d}$. nutartis civilinèje byloje Nr. 3K-3-20/2012.

20 Galima pritarti pozicijai, kad nekilnojamasis daiktas yra ne žemè apskritai, tačiau žemès sklypas. Žr. Mizaras, V., et al. Civilinè teisè. Bendroji dalis. Vilnius: Justitia, 2008, p. 460. CK 4.2 straipsnyje šis netikslumas yra ištaisytas ir vartojama būtent „žemès sklypo“ sąvoka. 
savarankiškais nekilnojamaisiais daiktais ${ }^{21}$, tačiau sodiniai ar ị statinio sąvoką nepatenkantys objektai (pavyzdžiui, terasai formuoti panaudoti akmenys) - ne, nes atskirti nuo žemès jie ịgytų jau kilnojamojo daikto statusą ${ }^{22}$. Taigi CK pabrèžia neatskirtų sodinių ar kitų susijungusių su žeme objektų priklausomybę nuo žemės sklypo. Kartu pripažintina, kad aptartoji norma yra pernelyg bendra ir stokojanti aiškumo, todèl praktinis jos taikymas sprendžiant susijungimo klausimus yra tik pagalbinis.

Antra, praktiniu požiūriu svarbesnė yra CK 4.40 straipsnio 1 dalis, nustatanti, kad žemės sklypo savininkui nuosavybės teise priklauso viršutinis žemės sklypo sluoksnis, ant žemės sklypo esantys statiniai bei jų priklausiniai, kiti nekilnojamieji daiktai, jeigu įstatymo ar sutarties nenustatyta kitaip. Tai yra įtvirtinta klasikinè superficies solo cedit taisyklè, reiškianti, kad viskas, kas susijungia su žemės sklypo paviršiumi, priklauso nuosavybès teise žemès sklypo savininkui. Kartu tai reiškia žemès sklypo savininko nuosavybès teisès igijimą ị visus prie žemès sklypo prijungtus daiktus ir nuosavybès teisès ị šiuos objektus praradimą kitiems asmenims. Tokiu būdu CK 4.40 straipsnio 1 dalis įtvirtina susijungimą kaip nuosavybès teisès ịgijimo ir praradimo pagrindą, tačiau šios normos taikymo sritis apribota susijungimo su žemės sklypu atvejais. Kartu ši norma yra dispozityvi ir šalių susitarimas gali nustatyti kitokias susijungimo pasekmes. CK 4.40 straipsnio 1 dali aiškinant sistemiškai su Lietuvos Respublikos civilinio kodekso patvirtinimo, įsigaliojimo ir igyvendinimo i̦statymo ${ }^{23} 31$ straipsniu, darytina išvada, kad žemès sklypas yra laikomas pagrindiniu daiktu, o statiniai - jo priklausiniais (CK 4.12-4.14, 4.19 straipsniai) $)^{24}$.

Trečia, CK 4.40 straipsnio 1 dalị papildo siauresnio pobūdžio teisès normos, ịtvirtinančios superficies solo cedit taisyklę konkrečių teisinių santykių atžvilgiu: pavyzdžiui, CK 4.105 straipsnio 1 dalis, nustatanti, kad asmeniui, teismo tvarka pripažintam praradusiu teisę ị žemės sklypą, atlyginama ant šio žemės sklypo esančių ir jam nuosavybès teise priklausančių statinių vertè, jeigu jam nesuteikiama teisẻ kitu teisètu būdu naudotis žemès sklypu; CK 4.105 straipsnio 2 dalis, nustatanti, kad sandorị, kurio pagrindu buvo naudojamasi žemès sklypu, teismo tvarka pripažinus negaliojančiu ne dẻl statinių savininko kaltès, statinių savininkui atlyginama CK 4.102 straipsnyje nustatyta tvarka ir sąlygomis žemès sklypo savininko lëšomis; CK 4.164 straipsnio 2 dalis, nustatanti, kad pasibaigus užstatymo teisei, nuosavybès teisè ì statinius ar sodinius pereina žemès savininkui, CK 6.557 straipsnio 1 ir, ypač, 2 dalys, ta apimtimi, kuria nustatoma, kad,

21 Lietuvos Respublikos kadastro įstatymo (Valstybės žinios. 2000, Nr. 58-1704) 5 straipsnio 1 dalyje Nekilnojamojo turto kadastro objektais laikomi šie nekilnojamieji daiktai: žemès sklypas; statinys (taip pat nebaigtas statyti), kurio statybai ar rekonstravimui reikalingas leidimas statyti naują statinị ar leidimas rekonstruoti statinị; patalpa, Kadastro ịstatymo nustatytais būdais suformuota kaip atskiras nekilnojamasis daiktas.

22 Pvz., Prancūzijos CC 520 straipsnis tiesiogiai numato, kad neatskirtas derlius bei medžių vaisiai laikomi nekilnojamuoju turtu, o atskirti - kilnojamuoju.

23 Valstybès žinios. 2000, Nr. 74-2262.

24 Tokio aiškinimo laikosi ir kasacinis teismas, žr. Lietuvos Aukščiausiojo Teismo Civilinių bylų skyriaus teisejjų kolegijos 2012 m. kovo 12 d. nutarti civilinėje byloje Nr. 3K-3-51/2012. Atkreiptinas dèmesys, kad Civilinio kodekso patvirtinimo, įsigaliojimo ir ígyvendinimo įstatymo 31 straipsnis apriboja CK 4.40 straipsnio 1 dalies taikymą. 
pasibaigus žemės nuomai, pastatyti pastatai, statiniai ir ịrenginiai pereina nuomotojui nuosavybės teise. Nurodytos teisės normos daugiau ar mažiau aiškiai kartoja bendrają susijungimo taisyklę, jog žemės sklypo paviršiuje kito, nei sklypo savininkas, asmens pastatyti statiniai, ǐrenginiai ar pasodinti sodiniai, pasibaigus žemės sklypo naudojimo pagrindui, tampa žemès sklypo savininko nuosavybe (kartu dažniausiai numatomi alternatyvūs tokių objektų nuosavybès išsprendimo būdai).

Ketvirta, CK 4.2 straipsnio 4-6 dalys tiesiogiai reguliuoja kilnojamųų daiktų susijungimo su nekilnojamuoju daiktu klausimus, iš kurių svarbiausia yra 4 dalies nuostata, jog kilnojamasis daiktas, įeinantis i nekilnojamajị daiktą ir praradęs savo individualius požymius, yra nekilnojamojo daikto dalis. Ši nuostata reiškia, kad trečiųu asmenų nuosavybés ar kitos daiktinės teisės ị tokị kilnojamajị daiktą pasibaigia, nes nebelieka paties nuosavybės teisès objekto. Šios normos iš dalies sutampa su aptartomis CK 1.98 straipsnio 2 dalimi ir CK 4.40 straipsnio 1 dalimi, tačiau jų taikymo sritis yra platesnè, nes apima susijungimą ne tik su žemès sklypu, bet ir su kitais nekilnojamaisiais daiktais, pirmiausia, statiniais.

Išdėstytą poziciją dèl CK 4.2 straipsnio 4-6 dalių patvirtina byla, kuri buvo nurodyta kaip pavyzdys šio straipsnio pradžioje. Kaip minèta, šioje byloje kilo klausimas dẻl kilnojamujuc daiktų - durų, langų ir stogo dangos prisijungimo prie pastato. Lietuvos Aukščiausiasis Teismas panaikino apygardos teismo nutartị ir bylą grąžino nagrinèti tuo pagrindu, jog šis teismas netinkamai taikẻ būtent CK 4.2 straipsnio 4 ir 5 dalis. Kasacinio teismo teigimu:

„apeliacinès instancijos teismas turejo taikyti CK 4.2 straipsnio nuostatas dèl nekilnojamujų ir kilnojamujų daiktu statuso. Šio straipsnio 4 dalyje nustatyta, kad kilnojamasis daiktas, ịeinantis i nekilnojamaji daiktą ir praradęs savo individualius požymius, yra nekilnojamojo daikto dalis. Taigi šiuo atveju svarbu išsiaiškinti, ar sumontuota stogo danga su visomis jos pridétinèmis dalimis (...) neịejo ị nekilnojamaji daikta - nama, ar sumontuota stogo danga neprarado savo individualiu požymiu, kaip nurodyta CK 4.2 straipsnio 4 ir 5 dalyse. Konstatavus, kad stogo danga, kaip kilnojamasis daiktas, iejo ì nekilnojamaji daikta (nama), neliktu pagrindo teigti, jog ji neperejjo kitu asmenu nuosavybèn. " 25

Nors kasacinis teismas plačiau neišdėstè, kaip reikètų aiškinti individualių požymių praradimą, tačiau pats apygardos teismo nutarties panaikinimo faktas patvirtina poziciją, jog, stogo dangai esant jau sumontuotai, tai liudija jos individualių požymių praradimo faktą ${ }^{26}$.

25 Lietuvos Aukščiausiojo Teismo Civilinių bylų skyriaus teisèjų kolegijos 2008 m. spalio 21 d. nutartis civilinèje bylioje Nr. 3K-3-491/2008.

26 Tuo labiau keista buvo bylos baigtis apygardos teisme, ją nagrinejant pakartotinai. Apygardos teismas liko prie savo ankstesnio sprendimo, jog rangovas vis dar buvo stogo dangos savininkas, todèl turèjo teisę ją atskirti ir pasiimti. Nepaisant kasacinio teismo išaiškinimų, apygardos teismas nenagrinejjo klausimo, ar sumontuota stogo danga laikytina praradusia individualius požymius. Vietoj to teismas remėsi rangos sutartị reglamentuojančiomis teisès normomis ir tuo, jog namo uždengimo darbai nebuvo iki galo baigti bei nesurašytas darbų prièmimo-perdavimo aktas. Tokioje motyvacijoje yra labai akivaizdus daiktinių ir prievolinių teisinių santykių supainiojimas. Žr. Klaipèdos apygardos teismo Civilinių bylų skyriaus teisèjų kolegijos 2009 m. birželio 17 d. nutartị civilinèje byloje Nr. 2A-175-360/2009. 
Penkta, susijungimo pasekmès yra sprendžiamos esminių daikto dalių reguliavimu, pateikiamu CK 4.12-4.15 straipsniuose. Esmines daikto dalis CK priskiria prie antraeilių daiktų, kuriuos ištinka pagrindinio daikto likimas, jeigu sutarties ar įstatymo nenustatyta kitaip (CK 4.14 straipsnis). Taigi, nesant ịstatymo ar sutarties, verčiančių daryti priešingą išvadą, daiktas, kuris atitinka esminès dalies požymius, laikytinas priklausančiu nuosavybės teise pagrindinio daikto savininkui, o trečiųjų asmenų nuosavybès teisè i ji - pasibaigusi.

Apimties požiūriu aptariama teisės normų grupė yra plačiausia, nes tiek pagrindinis daiktas, tiek esminè dalis nėra apriboti tik kilnojamaisiais ar tik nekilnojamaisiais daiktais. Būtent esminès dalies normos praktikoje yra dažniausiai naudojamos spręsti dèl nuosavybès teisès ịgijimo ar praradimo susijungimo pagrindu. Apibendrinant egzistuojančią teisminę praktiką, galima pastebèti, kad esminès dalies pripažinimo kriterijai aiškinami nevienodai. Dažniausiai taikomas savarankiškumo kriterijus, tai yra vertinama, ar daiktas (daikto dalis), dèl kurio kilo ginčas, gali funkcionuoti savarankiškai, jei negali - tai yra esminè daikto dalis ${ }^{27}$. Tačiau nesenoje Lietuvos Aukščiausiojo Teismo išspręstoje byloje buvo pateiktas kiek kitoks esminès dalies aiškinimas:

„Kriterijus, pagal kuri daiktas kvalifikuojamas esmine pagrindinio daikto dalimijo neatskiriamas funkcinis ryšys su pagrindiniu daiktu - toks, kad pagrindinis daiktas be esmines dalies netenka savo naudingumo, nes netenkina poreikiu, kuriems yra skirtas; savo ruožtu, esmine daikto dalis neturi savarankiškos paskirties - jos funkcija yra užtikrinti pagrindinio daikto atitiktị tikslinei paskirčiai, be pagrindinio daikto esmine jo dalimi esantis daiktas nenaudingas. Daikto kvalifikavimas esmine pagrindinio daikto dalimi ịstatyme nesiejamas su daiktu tarpusavio išsidestymu erdveje ar kitais fiziniais požymiais, todèl ydingu laikytinas argumentas, kad pastato esminèmis dalimis gali büti tik tie daiktai, kurie yra jo viduje." ${ }^{\text {"28 }}$

Nepaisant to, koks tiksliai kriterijus taikomas sprendžiant dèl esminès dalies statuso, tačiau visais atvejais esminè dalis nèra pripažĭstama galinti būti savarankišku nuosavybės teisè objektu, o tai reiškia visų trečiujų asmenų teisių ị šį objektą praradimą.

Šešta, su susijungimu yra susijusi dar viena grupe teisès normų, reglamentuojančių daikto pagerinimo pasekmes: pavyzdžiui, CK 4.34 straipsnio 3 dalis, 4.97 straipsnio 4 dalis, 4.158 straipsnio 2 dalis, 6.501 straipsnio 2 ir 3 dalys. Nors tiesiogine nurodytų teisès normų paskirtis yra įtvirtinti susijungimo taisyklès išimtį, pagerinimus padariusiam daikto valdytojui suteikiant teisę atskirti savo atliktus pagerinimus (ius tollendi), tačiau kartu išimtis tik patvirtina taisyklę - visos nurodytos normos įtvirtina taisyklę, kad pagerintų dalių nebegalint atskirti, valdytojui paprastai sumokama atitinkama kompensacija. Tai suponuoja daiktinę teisinę pasekmę, kad pastaruoju atveju valdytojas laikomas praradusiu nuosavybės teisę ị pagerintas dalis, o pagrindinio daikto savininkas - igijusiu

27 Lietuvos Aukščiausiojo Teismo Civilinių bylų skyriaus teisèjų kolegijos 2005 m. birželio 6 d. nutartis civilinèje byloje Nr. 3K-3-322/2005; $2006 \mathrm{~m}$. kovo 27 d. nutartis civilinèje byloje Nr. 3K-3222/2006; 2008 m. lapkričio 4 d. nutartis civilinėje byloje Nr. 3K-3-550/2008.

28 Lietuvos Aukščiausiojo Teismo Civilinių bylų skyriaus teisèjų kolegijos $2010 \mathrm{~m}$. liepos 2 d. nutartis civilinèje byloje Nr. 3K-3-306/2010. 
i jas nuosavybės teisę. Sistemiškai vertinant, tai laikytina esminès dalies taisyklès (CK 4.14 straipsnio) taikymo konkrečioms situacijoms atvejai.

Apibendrinant anksčiau išdèstytą reglamentavimą galima daryti vienareikšmę išvadą, kad susijungimas, kaip nuosavybès teisès igijimo ir praradimo pagrindas, Lietuvos teisèje yra pripažistamas ir taikomas tiek kilnojamųjų, tiek nekilnojamųjų daiktų atžvilgiu. Kartu pastebėtinas ir ženklus teisinio reglamentavimo nenuoseklumas, nes bendrosios susijungimą reglamentuojančios teisès normos yra išmėtytos skirtinguose CK 4 knygos skyriuose: kilnojamujų daiktų susijungimas su nekilnojamaisiais (CK 4.2 straipsnio 4-6 dalys) - I skyriuje, esminès dalies institutas - II skyriuje, superficies solo cedit taisyklè (CK 4.40 straipsnio 1 dalis) įtvirtinta V skyriaus pirmajame skirsnyje, galiausiai CK 4.54 straipsnis - V skyriaus antrajame skirsnyje, skirtame nuosavybès teisės igijimui ir praradimui. Be to, iš esmès tos pačios susijungimo pasekmés reglamentuojamos keliomis skirtingomis, iš dalies sutampančiomis, iš dalies besiskiriančiomis teisès normomis, ypač keblus atrodo CK 4.2 straipsnio 4-6 dalių santykis su esminès dalies institutu $^{29}$. Nurodytos priežastys apsunkina nuoseklų susijungimo instituto suvokimą ir jo taikymą.

Tačiau vertinant sistemiškai bei atsižvelgiant ị anksčiau aptartą kitų valstybių teisinị reglamentavimą, galima išvesti tokias susijungimo reglamentavimo Lietuvos Respublikoje pagrindines nuostatas.

Pirma, Lietuvos Respublikos civiliniuose įstatymuose nèra vienos bendros teisès normos, skirtos reglamentuoti daiktų susijungimą, tačiau pakankamai aiškiai galima išskirti kilnojamojo daikto susijungimo su nekilnojamuoju ir kilnojamujų daiktų susijungimo atvejus.

Antra, pagrindinė kilnojamojo daikto susijungimo su nekilnojamuoju taisyklè, kaip ir kitose nagrinètose jurisdikcijose, yra superficies solo cedit (CK 4.40 straipsnio 1 dalis), tačiau numatyta nemažai šios taisyklès apribojimų ir išimčių, viena jų - šalys gali susitarti dèl kitokių susijungimo pasekmių. Ją papildo CK 4.2 straipsnio 4-6 dalys, kurių praktine taikymo sritis dažniausiai bus apribota kilnojamųjų daiktų susijungimo su statiniais atvejais ${ }^{30}$.

Trečia, kalbant apie kilnojamuosius daiktus, jei susijungusius daiktus galima atskirti, tuomet susijungimas kaip nuosavybès teisès igijimo ir praradimo pagrindas netaikomas, nuosavybès teisè ị susijungusius daiktus nepakinta, ir tokius daiktus savininkai gali reikalauti atskirti ir grąžinti jiems; specialus pastarosios situacijos atvejis reglamentuojamas CK 4.54 straipsnio 2 dalyje.

Ketvirta, jei susijungusių kilnojamųjų daiktų atskirti nėra įmanoma, lemiamą reikšmę igyja aplinkybè, ar vienas iš daiktų gali būti pagrindiniu, o kitas (kiti) - šalutiniu. Jei

29 Neatitikimą ir prieštaravimą galima paaiškinti ne iki galo sėkmingu teisinių transplantų suderinimu: CK 4.2 straipsnio 4, 6 dalys atitinka Kanados Kvebeko kodekso 901-902 straipsnius, tuo tarpu CK 4.12-4.15 straipsniai didžiaja dalimi yra Latvijos Respublikos civilinio įstatymo 850-854 straipsnių atitikmenys. Natūralu, kad iš skirtingų teisnių kontekstų paimtos sąvokos nedera tarpusavyje.

30 Be to, reikia atkreipti dèmesį, kad tokiu atveju visiškai įmanoma taikyti ir CK 4.12-4.15 straipsnius. Toks teisès normų dubliavimas gali sukelti praktinių problemų, nes CK 4.6 straipsnyje ir CK 4.15 straipsnyje nustatyti skirtingi susijungimo kriterijai. 
taip - tuomet taikytinos CK 4.12-4.15 straipsnių nuostatos, ir nuosavybės teisė ị šalutinị daiktą, kaip esminę daikto dalį, pasibaigia. Tačiau kartu CK 4.14 straipsnis numato, kad įstatymas ir, svarbiausia, sutartis gali nustatyti kitaip.

Penkta, jei susijungusių kilnojamųjų daiktų atskirti nèra įmanoma ir né vienas iš susijungusių daiktų negali būti laikomas pagrindiniu, susijungusių daiktų savininkai tampa bendraturčiais, turinčiais bendrosios dalinės nuosavybès teisę ị naują kilnojamaji daiktą (CK 4.54 straipsnio 1 dalis).

\section{Išvados}

I klausimą, iškeltą straipsnio ịvade, - ar šiuo metu veikiančioje Lietuvos civilinejje teisèje galima išskirti susijungimą kaip savarankišką nuosavybės teisès įgijimo ir praradimo pagrindą - reikia atsakyti vienareikšmiškai teigiamai. Nors teisès normos, reglamentuojančios susijungimą (svarbiausios jų - CK 4.2 straipsnių 4-6 dalys, 4.12-4.15 straipsniai, 4.40 straipsnio 1 dalis), yra ne visai nuosekliai išdèstytos įvairiose CK struktūrinèse dalyse, tačiau jų pagrindinè funkcija yra sukelti būtent nuosavybès teisès pasibaigimo vienam asmeniui (šalutinio, antraeilio daikto savininkui) ir nuosavybès teisès pripažinimo ị visą pagrindinị daiktą pastarojo savininkui teisinị efektą. Be to, CK reglamentavime pakankamai aiškiai galima išskirti kilnojamojo daikto susijungimo su nekilnojamuoju ir kilnojamųų daiktų susijungimo atvejus. Toks reguliavimas esminiais bruožais atitinka ir kitų analizuotų Europos valstybių teisę bei Bendrosios pagrindų sistemos projektą.

\section{Literatūra}

Baranauskas, E., et al. Daiktinè teisè. Vadovèlis. Vilnius: Mykolo Romerio universiteto Leidybos centras, 2010.

Cases, Materials and Text on Property Law. Ed. Van Erp S., Akkermans B. Oxford and Portland, Oregon: Hart Publishing, 2012.

Klaipèdos apygardos teismo Civilinių bylų skyriaus teisèjų kolegijos 2009 m. birželio 17 d. nutartis civilinèje byloje Nr. 2A-175360/2009.

Kvebeko civilinis kodeksas (Code Civil du Québec) [interaktyvus]. [žiūrèta 2013-0728]. <http://www2.publicationsduquebec. gouv.qc.ca/lois_et_reglements/liste_alpha. php?lettre $=$ C\#CCQ-1991>.

Latvijos Respublikos civilinis ịstatymas (Latvijas Republikas civillikums) [interaktyvus]. [žiūrèta 2013-07-28]. <http://likumi.lv/doc. php?id=225418>.

Lietuvos Aukščiausiojo Teismo Civilinių bylų skyriaus teisèjų kolegijos $2005 \mathrm{~m}$. birželio $6 \mathrm{~d}$. nutartis civilinèje byloje Nr. 3K-3322/2005.

Lietuvos Aukščiausiojo Teismo Civilinių bylų skyriaus teisèjų kolegijos 2006 m. kovo $27 \mathrm{~d}$. nutartis civilineje byloje Nr. 3K-3-222/2006.

Lietuvos Aukščiausiojo Teismo Civilinių bylų skyriaus teisèjų kolegijos 2008 m. lapkričio 4 d. nutartis civilineje byloje Nr. 3K-3550/2008.

Lietuvos Aukščiausiojo Teismo Civilinių bylų skyriaus teisèjų kolegijos 2008 m. spalio 
21 d. nutartis civilineje byloje Nr. 3K-3491/2008.

Lietuvos Aukščiausiojo Teismo Civilinių bylų skyriaus teisèjų kolegijos 2010 $\mathrm{m}$. liepos $2 \mathrm{~d}$. nutartis civilineje byloje Nr. 3K-3-306/2010.

Lietuvos Aukščiausiojo Teismo Civilinių bylų skyriaus teisèjų kolegijos $2012 \mathrm{~m}$. vasario 8 d. nutartis civilineje byloje Nr. 3K-320/2012.

Lietuvos Aukščiausiojo Teismo Civilinių bylų skyriaus teisejų kolegijos $2012 \mathrm{~m}$. kovo $12 \mathrm{~d}$. nutartis civilinejje byloje Nr. 3K-3-51/2012.

Lietuvos Respublikos civilinis kodeksas. Valstybès žinios. 2000, Nr. 74-2262.

Lietuvos Respublikos civilinio kodekso patvirtinimo, įsigaliojimo ir igyvendinimo įstatymas. Valstybès žinios. 2000, Nr. 74-2262.

Lietuvos Respublikos nekilnojamojo turto kadastro įstatymas. Valstybès žinios. 2000, Nr. 58-1704.

Malaurie, Ph.; Aynes, L. Cours de droit civil. Les Biens. Paris: Cujas, 1994.

Mizaras, V., et al. Civiline teisé. Bendroji dalis. Vilnius: Justitia, 2008.

Nekrošius, I.; Nekrošius, V.; Vèlyvis, S. Roménu teise. Vilnius: Justitia, 1999.

Vokietijos Federacinès Respublikos civilinis kodeksas (Bürgerliches Gesetzbuch) [interaktyvus]. [žiūrèta 2013-07-28]. <http:// www.gesetze-im-internet.de/bgb/index. html>.

Prancūzijos Respublikos civilinis kodeksas (Code civil) [interaktyvus]. [žiūrèta 2013-07-28]. $<$ http://www.legifrance.gouv.fr/affichCode. do?cidTexte=LEGITEXT000006070721>.

Principles of European Law. Acquisition and Loss of Ownership of Goods. Sellier European Law Publishers, 2011.

Storme, E. M. Property Law in Comparative Perspective. Part I. General Notions. [interaktyvus]. KU Leuven Centre for Advanced Legal Studies, 2004 [žiūrèta 2013-07-28]. <http://www.storme.be/ comprop1.pdf $>$.

Šveicarijos Konfederacijos civilinis kodeksas (Code civil suisse) [interaktyvus]. [žiūrèta 2013-07-28]. <http://www.admin.ch/opc/ fr/classified-compilation/19070042/index. html> .

van Zyl, D. H. History and Principles of Roman Law. Durban: Butterworths, 1983.

Van Vliet, L. P. W. Accession of Movables to Land: I. Edinburg Law Review. 2002, 6.

Van Vliet, L. P. W. Accession of Movables to Land: II. Edinburg Law Review. 2002, 6.

Vèlyvis, S.; Jonaitis, M. XII lenteliu istatymai ir ju komentaras. Vilnius: Teisinès informacijos centras, 2007.

\title{
ACCESSION AS A MODE OF ACQUISITION AND LOSS OF OWNERSHIP IN THE LITHUANIAN CIVIL LAW
}

\author{
Ramūnas Birštonas
}

Mykolas Romeris University, Lithuania

Summary. The aim of the article is to answer the question if accession can be maintained as a separate and independent mode of acquisition and loss of ownership in the Lithuanian civil law. Although this mode takes its beginning in the Roman law and is well-known in other European jurisdictions, the situation in Lithuania is less clear because the accession is almost totally absent from the legal texts of the Lithuanian positive civil law, court decisi- 
ons and legal doctrine as well. Thus, a legal analysis confined to the linguistic analysis of law would come to the conclusion that Lithuanian law functions without the accession. Nevertheless, a deeper analysis of the Lithuanian Civil Code and case law reveals a different view.

To respond to the posed question, the article analyses the functions and the concept of accession as one of the aspects of a broader property law principle, namely, of unity. The essence of the latter is that one thing presupposes one right of ownership and it is inconceivable to hold several full ownerships into the same thing. In this respect, accession plays an important role protecting the legal interests of the third parties. Also, the application of accession in other continental European countries and the solutions proposed by the Draft Common Frame of Reference is analysed.

Further, the analysis turns to the Lithuanian positive law and case law. In spite of the lack of express reference to the accession rule, careful analysis shows that, in fact, the accession rule is established in the Lithuanian Civil Code, albeit it could be found in various forms and in several different units of the Civil Code. Also, Lithuanian courts routinely apply the rules on accession in practice. Even more, the analysis shows that the Lithuanian Civil Code is not devoid of the rules of accession, but, on the opposite, this legal institute is over-regulated and, in part, incoherent. This quality can be explained as a consequence of an imprecise legal drafting. The final conclusion is drawn that accession is a separate and fully working legal institute of Lithuanian civil law, although to reach its coherent application a certain interpretative position should be adopted.

Keywords: property right, thing, ownership, accession, Civil Code.

Ramūnas Birštonas, Mykolo Romerio universiteto Teisès fakulteto Civilinès justicijos instituto docentas. Mokslinių tyrimų kryptys: intelektinès nuosavybės teisé, daiktinè teisé, civilinè atsakomybė.

Ramūnas Birštonas, Mykolas Romeris University, Faculty of Law, Institute of Civil Justice, Associate Professor. Research interests: intellectual property law, property law, tort law. 